\title{
Laboratory Experiment Research on Multi-slug Alternative Injection Method of Polymer Flooding
}

\author{
Bin Huang ${ }^{1,2, a, \star}$, Cheng $\mathrm{Fu}^{2, \mathrm{~b}, *}$ \\ ${ }^{1}$ Beijing Deweijiaye Technology Corporation Ltd., Beijing, China,100027 \\ ${ }^{2}$ College of Petroleum Engineering, Northeast Petroleum University, Daqing, China,163318 \\ ahuangbin0201@126.com, ${ }^{\mathrm{b} * 1852074901 @ q q . c o m}$ \\ *these authors contributed equally to this work
}

Keywords: enhanced oil recovery; polymer flooding; alternative injection; concentration gradually decreased injection

\begin{abstract}
On simulation of reservoir conditions in Daqing Oilfield, the effect of different method of multi-slug alternative injection, concentration gradually decreased injection, and concentration increasing injection on oil displacement efficiency are studied by laboratory experiment. The experimental results show that, under the condition of the same total amount of polymer, recovery percent of reserves of polymer flooding stage will increase with the increase of polymer concentration. The scheme which using the concentration gradually decreased method, the extent of enhancing recovery is maximum, polymer flooding recovery can reach $40.12 \%$, and the ultimate recovery can reach $80.48 \%$.
\end{abstract}

\section{Introduction}

At present, polymer flooding technology has been popularized in various fields of the whole country, oil was produced by polymer flooding in Daqing oil field has reached the scale of $1000 \times 10^{4} \mathrm{t}$, Shengli oilfield achieved an annual output about $300 \times 10^{4} \mathrm{t}$ oil, increased the oil recovery rate of more than $10 \%$, enhanced oil recovery is about $7 \%$, which has achieved great economic benefits. Other such as Liaohe, Dagang, Xinjiang, Henan and Bohai oilfield, etc. The same experiment was carried out, which has achieved good results[1]. The polymer flooding has become an important technology of oilfield development. To improve the oil recovery mechanism of polymer, In recent years, the literature showed polymer not only increase the macroscopic sweep efficiency, because its viscoelasticity also can improve the microscopic oil displacement efficiency[2], literature[3] showed that the high mass concentration of polymer is more advantageous to enhance oil recovery. Different scholars studied the effects of different kinds of methods and combinations of polymer injection on the recovery[4,5]. In this text, polymer flooding conditions in the simulation of Daqing, indoor experiments showed the effects of different concentrations and different combinations of high molecular weight polymer slug on oil, provided basis for the scene to carry out high concentration polymer.

\section{Experimental Condition}

Model. Artificial quartz sand epoxy cemented rectangular core with $4.5 \times 4.5 \times 30 \mathrm{~cm}$, the model is vertical heterogeneity, positive rhythm and the coefficient of variation was $0.72, \mathrm{Kg}=0.85 \mu \mathrm{m}^{2}$.

Experimental Oil. Crude oil and kerosene mixed with simulated oil was mixed by crude oil and kerosene in No.3 Oil Production Plant of Daqing Oilfield, the simulated oil viscosity of 45 degrees Celsius is about $10 \mathrm{mPa}$.s.

The Experimental Water. Displacement and distribution of liquid water are synthetic brine, the mineralization degree of saturation model water is $6778 \mathrm{mg} / \mathrm{L}\left(\mathrm{CaCl}_{2} 64 \mathrm{mg} / \mathrm{L}, \mathrm{MgSO}_{4} 262 \mathrm{mg} / \mathrm{L}\right)$, the mineralization degree of polymer water is $508 \mathrm{mg} / \mathrm{L}\left(\mathrm{CaCl}_{2} 22 \mathrm{mg} / \mathrm{L}, \mathrm{MgSO}_{4} 61 \mathrm{mg} / \mathrm{L}\right)$, the mineralization degree of core displacement with water is $3700 \mathrm{mg} / \mathrm{L}\left(\mathrm{CaCl}_{2} 35 \mathrm{mg} / \mathrm{L} \mathrm{MgSO}_{4}, 143\right.$ $\mathrm{mg} / \mathrm{L})$. 
Experimental Polymer. Molecular weight of the salt tolerance polyacrylamide is $2.5 \times 10^{7}$ (copolymer), molecular weight of the ordinary polyacrylamide is $1.7 \times 10^{7}$ (HPAM). At the temperature of 45 degrees Celsius, the viscosity of polymer solution with different concentration was tested at $7.34 \mathrm{~S}^{-1}$ shear velocity, the test results: the viscosity of $1000 \mathrm{mg} / \mathrm{L}$ is $42.1 \mathrm{mPa} . \mathrm{s}$, $1500 \mathrm{mg} / \mathrm{L}$ to $58.5 \mathrm{mPa} . \mathrm{s}, 2000 \mathrm{mg} / \mathrm{L}$ to $79.5 \mathrm{mPa} . \mathrm{s}, 2500 \mathrm{mg} / \mathrm{L}$ to $111.9 \mathrm{mPa} . \mathrm{s}, 3000 \mathrm{mg} / \mathrm{L}$ to 134.6mPa.s.

The Experimental Temperature. All the experiments were carried out at 45 degrees Celsius.

\section{Experimental Procedure}

Selected the appropriate core, vacuumed 3 hours or more, the mineralization degree of artificial synthetic brine is $6778 \mathrm{mg} / \mathrm{L}$, in order to measure porosity and water permeability. The saturated model is placed in the constant temperature of 45 degrees Celsius for more than 12 hours. The oil drive water when the model has no water at 45 degree Celsius, in order to determine the original oil saturation. Counted water flooding recovery when the model is exported to more than $98 \%$ water at displacement rate of $1 \mathrm{~m} / \mathrm{d}$. Drew up different experimental plans on the premise of the same total polymer content, injected polymer slug according to different schemes. Counted polymer flooding recovery and total recovery when the model is exported to more than $98 \%$ water.

\section{Effect of High Concentration Polymer Slug Combination on Oil Displacement}

Experimental Scheme. Table 1 shows the injection schemes of different polymer slug combinations. Table 2 shows the effect of different experimental schemes on the oil displacement.

Table 1 experimental schemes of different polymer slug combinations

\begin{tabular}{cc}
\hline $\begin{array}{c}\text { Scheme } \\
\text { number }\end{array}$ & Injection mode \\
\hline 1 & $\mathrm{~W} 1+\mathrm{P}(1000 \mathrm{mg} / \mathrm{L}, 2.00 \mathrm{PV})+\mathrm{W} 2$ \\
2 & $\mathrm{~W} 1+\mathrm{P}(1500 \mathrm{mg} / \mathrm{L}, 1.33 \mathrm{PV})+\mathrm{W} 2$ \\
3 & $\mathrm{~W} 1+\mathrm{P}(2000 \mathrm{mg} / \mathrm{L}, 1.00 \mathrm{PV})+\mathrm{W} 2$ \\
4 & $\mathrm{~W} 1+\mathrm{P}(2500 \mathrm{mg} / \mathrm{L}, 0.80 \mathrm{PV})+\mathrm{W} 2$ \\
5 & $\mathrm{~W} 1+\mathrm{P}(3000 \mathrm{mg} / \mathrm{L}, 0.67 \mathrm{PV})+\mathrm{W} 2$ \\
6 & $\mathrm{~W} 1+\mathrm{P}(3000 \mathrm{mg} / \mathrm{L}, 0.13 \mathrm{PV}+2500 \mathrm{mg} / \mathrm{L}, 0.16 \mathrm{PV}+$ \\
7 & $\mathrm{~W} 1+\mathrm{P}(1000 \mathrm{mg} / \mathrm{L}, 0.40 \mathrm{PV}+1500 \mathrm{mg} / \mathrm{L}, 0.27 \mathrm{PV}+$ \\
& $2000 \mathrm{mg} / \mathrm{L}, 0.20 \mathrm{PV}+1500 \mathrm{mg} / \mathrm{L}, 0.27 \mathrm{PV}+1000 \mathrm{mg} / \mathrm{L}, 0.40 \mathrm{PV})+\mathrm{W} 2$ \\
\hline
\end{tabular}

Note: the total amount of polymer is $2000 \mathrm{PVmg} / \mathrm{L}, \mathrm{W} 1-$ water flooding to model outlet water cut 98\%; W2 - follow water drive to model outlet water cut 98\%; P - polymer flooding

Table 2 Effect of different experimental schemes on oil displacement

\begin{tabular}{ccccccc}
\hline $\begin{array}{c}\text { Scheme } \\
\text { number }\end{array}$ & $\begin{array}{c}\text { Permeability } \\
{\left[\mu \mathrm{m}^{2}\right]}\end{array}$ & $\begin{array}{c}\text { porosity } \\
{[\%]}\end{array}$ & $\begin{array}{c}\text { oil } \\
\text { saturation } \\
{[\%]}\end{array}$ & $\begin{array}{c}\text { recovery ratio [\%] } \\
\text { flooding }\end{array}$ & $\begin{array}{c}\text { Polymer } \\
\text { flooding }\end{array}$ & Total \\
\hline 1 & 0.785 & 26.14 & 72.31 & 41.16 & 28.55 & 69.71 \\
2 & 0.779 & 26.16 & 70.49 & 42.11 & 32.01 & 74.12 \\
3 & 0.862 & 26.53 & 73.33 & 42.72 & 33.42 & 76.14 \\
4 & 0.854 & 26.38 & 69.62 & 40.86 & 36.45 & 77.31 \\
5 & 0.807 & 26.71 & 72.39 & 40.33 & 36.71 & 77.04 \\
6 & 0.797 & 25.92 & 71.85 & 40.36 & 40.12 & 80.48 \\
7 & 0.795 & 25.55 & 72.36 & 41.19 & 34.67 & 75.86 \\
\hline
\end{tabular}




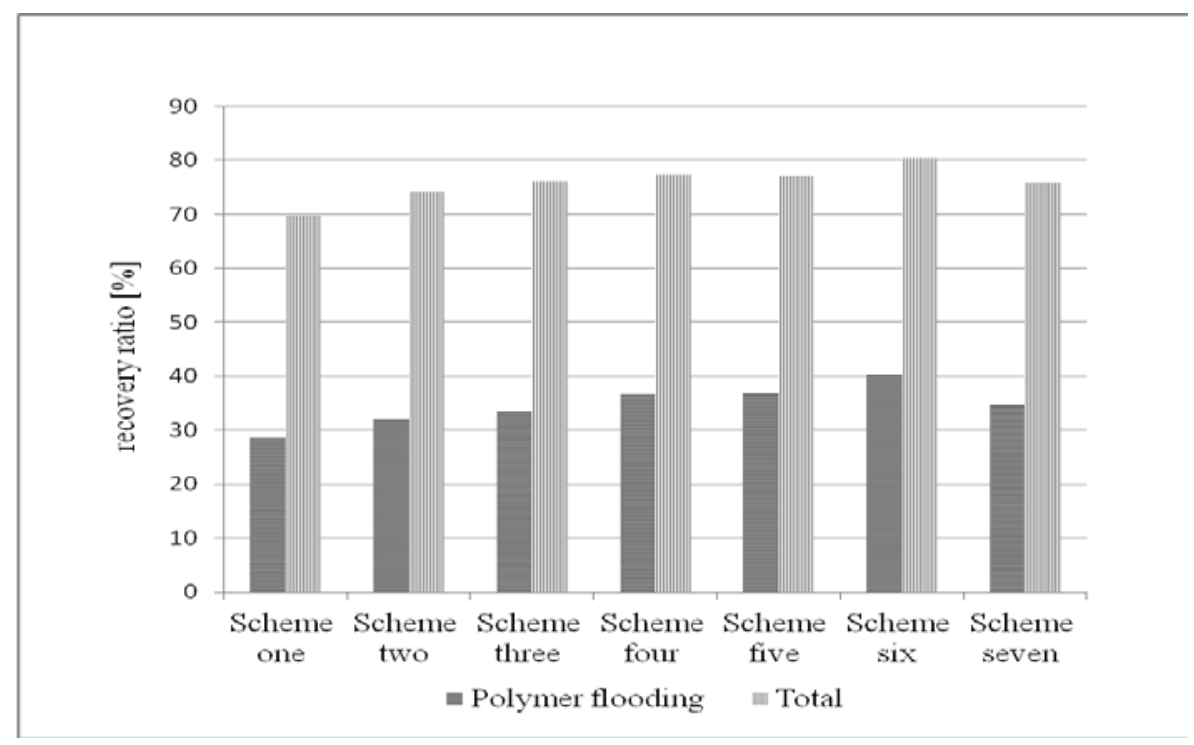

Fig. 1 Comparison of different experimental schemes on the effect of oil displacement

Experimental Results and Discussion. With the concentration of high molecular weight of polymer increasing, the polymer flooding efficiency increasing in the same amount of polymer. Compared scheme 1 to 5 , the polymer flooding recovery ratio is less than $30 \%$ when the polymer concentration is $1000 \mathrm{mg} / \mathrm{L}$, the final recovery rate is lower than $70 \%$, below the recovery in other concentration of polymers. The polymer recovery was $28.55 \%$ when the polymer concentration is $1000 \mathrm{mg} / \mathrm{L}, 1500 \mathrm{mg} / \mathrm{L}$ corresponding to $32.01 \%$, $2000 \mathrm{mg} / \mathrm{L}$ corresponding to 33.42\%, $2500 \mathrm{mg} / \mathrm{L}$ corresponding to $36.45 \%, 3000 \mathrm{mg} / \mathrm{L}$ corresponding to $36.71 \%$, polymer flooding recovery and ultimate recovery rate increased step by step, but from $2500 \mathrm{mg} / \mathrm{L}$ to $3000 \mathrm{mg} / \mathrm{L}$ increased significantly. It showed that more high viscoelastic concentration polymer solution on residual oil recovery and improved the mobility more effect than expanded at the same time, the sweep volume and improve displacement efficiency. Comparison of scheme 6 and other programs, scheme 6 obtained the highest polymer recovery and ultimate recovery, analyzed the reasons, because of the high concentration of polymer slug injection, polymer with short follow-up plug, and continued to reduce the viscosity of the polymer, and avoided the formation of fingering and dash, expanded the swept volume of polymer. scheme 7, easy to form the fingering and dart phenomenon due to the change of low concentration slug to high concentration slug, and did not get a higher recovery.

\section{Conclusion}

In the same amount of polymer, with the concentration of high molecular weight polymer increasing, the polymer flooding recovery yield increasing, the concentration increased to a certain value, the increase of the oil recovery rate decreased.

Enhanced oil recovery of the largest when used of small pieces of plug and continue to reduce the viscosity of the polymer flooding.

\section{Acknowledgement}

This project is financially supported by Science and Technology Research Project of Heilongjiang Province Department of Education (12531074).

\section{References}

[1] Han Dakuang. Present situation of oil and gas field development in China, facing the challenge of development and direction of technology [J]. Chinese Engineering Science, 2010, 12 (5): 51-57.

[2] Wang Demin, Cheng jiecheng, Yang Qingyan. Study on Mechanism of improving the efficiency of micro displacement by viscoelastic polymer solution [J].Petroleum Journal, 2000, 21 (5):45-51. 
[3] Yang Fulin, Yang Xizhi, Wang Demin, etc. High mass concentration polymer flooding method [J]. Journal of Daqing Petroleum Institute, 2003, 27 (4):24-26.

[4] Gaoming, Song Kaoping, Ye Yinzhu, etc. experimental study on enhanced oil recovery by high concentration polymer flooding in two kinds of reservoirs of Lamadian Oil field[J]. Oil field chemistry, 2010, 27 (2):158-161.

[5] Song Kaoping, Ren Gang, Xia Huifen, etc. Polymer flooding enhanced oil recovery method for variable viscosity polymer flooding [J]. Journal of Northeast Petroleum University, 2010, 34 (5): 71-74. 